\title{
Mitochondrial DNA mutations in renal disease: an overview
}

\author{
Larissa P. Govers ${ }^{1} \cdot$ Hakan R. Toka $^{2} \cdot$ Ali Hariri $^{3} \cdot$ Stephen B. Walsh ${ }^{1} \cdot$ Detlef Bockenhauer $^{1,4}$ (D)
}

Received: 23 August 2019 / Revised: 12 October 2019 / Accepted: 16 October 2019 / Published online: 10 January 2020

(C) The Author(s) 2020

\begin{abstract}
Kidneys have a high energy demand to facilitate the reabsorption of the glomerular filtrate. For this reason, renal cells have a high density of mitochondria. Mitochondrial cytopathies can be the result of a mutation in both mitochondrial and nuclear DNA. Mitochondrial dysfunction can lead to a variety of renal manifestations. Examples of tubular manifestations are renal Fanconi Syndrome, which is often found in patients diagnosed with Kearns-Sayre and Pearson's marrow-pancreas syndrome, and distal tubulopathies, which result in electrolyte disturbances such as hypomagnesemia. Nephrotic syndrome can be a glomerular manifestation of mitochondrial dysfunction and is typically associated with focal segmental glomerular sclerosis on histology. Tubulointerstitial nephritis can also be seen in mitochondrial cytopathies and may lead to end-stage renal disease. The underlying mechanisms of these cytopathies remain incompletely understood; therefore, current therapies focus mainly on symptom relief. A better understanding of the molecular disease mechanisms is critical in order to improve treatments.
\end{abstract}

Keywords Mitochondrial DNA · Renal disease $\cdot$ Renal Fanconi syndrome $\cdot$ Distal tubulopathies $\cdot$ Nephrotic syndrome Tubulointerstitial nephritis

\section{Introduction}

Mitochondria are important organelles with the main function of converting the energy derived from oxidative phosphorylation into a "fuel" in the form of adenosine triphosphate (ATP), that can be used to catalyse cellular processes. Other important functions include calcium storage, regulation of metabolism and apoptosis, and cell signalling [1]. Mitochondria are present in all eukaryotic cells apart from mature red blood cells, which means that any organ has the possibility to be affected by mitochondrial dysfunction, resulting in a wide spectrum of manifestations [2]. Collectively, disorders of mitochondrial function are referred to as "mitochondrial cytopathies". Even though our understanding of the mitochondria and its genome

Detlef Bockenhauer

d.bockenhauer@ucl.ac.uk

1 Department of Renal Medicine, University College London, London, UK

2 Manatee Kidney Diseases Consultants, Bradenton, USA

3 Clinical Development, Sanofi Rare Disease, Boston, USA

4 Renal Unit, Great Ormond Street Hospital for Children NHS Foundation Trust, Great Ormond Street, London, UK is increasing, the underlying mechanisms of these cytopathies remain incompletely understood to this day. Their estimated prevalence is around 1 in 5000, but this may be an underestimation as a substantial number of patients with a mitochondrial cytopathy caused by a mitochondrial DNA (mtDNA) mutation might be eluding diagnosis $[3,4]$.

Mitochondrial disorders are best known to affect the nervous system and muscles, but essentially all organs can be involved. The kidneys together with the heart have the highest energy demand of all organs when corrected for organ weight $[5,6]$. Renal cells are therefore rich in mitochondria and depend on mitochondrial aerobic respiration to facilitate the energy-consuming task of reabsorption of the majority of the glomerular filtrate. Proximal tubulopathy is the most commonly recognised renal phenotype in children with mitochondrial disorders, since the proximal tubule not only has a highenergy demand but also lacks the capability to synthesis ATP anaerobically from glycolysis [7]. However, distal tubular defects, especially hypomagnesaemia, are also increasingly recognised as a renal manifestation of mitochondrial cytopathies [8]. The majority of mitochondrial proteins are encoded by the nuclear genome and mitochondrial cytopathies can therefore usually be explained by traditional Mendelian genetics. The mitochondrial genome and its genetics are, however, different from the nuclear genome and 
Mendelian genetics in various aspects. These differences result in interesting biological and clinical consequences.

While mtDNA mutations are typically inherited from the mother, they can also occur de novo. Moreover, a number of nuclear genes are responsible for proper maintenance of mtDNA and mutations in these genes can therefore lead to quantitative (mtDNA depletion) and qualitative defects (mtDNA deletions) defects in mtDNA [9]. In this review, we will focus on renal diseases caused by genetic mutations in mitochondrial DNA.

\section{Mitochondrial genome and genetics}

\section{Genome}

The mitochondrial genome is a circular, double-stranded DNA molecule with a length of 16,569 base pairs. It contains 37 genes, encoding 22 tRNA, 2 rRNAs and 13 polypeptides (Fig. 1) [10]. Unlike the nuclear DNA, there are no intervening sequences and the entire mtDNA is either coding or involved in the regulation of transcription [11]. Both the tRNAs and rRNAs are involved in the intramitochondrial synthesis of proteins. The polypeptides are part of the five complexes involved in oxidative phosphorylation (OXPHOS). The complexes can be divided into two parts, complexes I-IV constitute the electron transport chain, while complex $\mathrm{V}$ is involved in the generation of ATP [12]. Approximately 1500 proteins are localised inside the mitochondria, of which 90 are involved in OXPHOS; most are encoded by nuclear genes [13]. Indeed, complex II is completely encoded by nuclear DNA, while the other complexes contain subunits that are derived from both nuclear and mitochondrial DNA (Table 1) [12]. There is also evidence that nuclear tRNAs are transported into mitochondria [19]. This dual genetic control contributes to the heterogeneity in clinical phenotypes.

Transcription of mtDNA occurs continuously on both strands, independent of the cell cycle and it also occurs in non-dividing cells. The strands are called heavy $(\mathrm{H})$, encoding for 12 protein subunits, 2 rRNAs, and 14 tRNAs, and light (L), which encodes for 1 mRNA and 8 tRNAs [20]. The main noncoding region is called the displacement loop (D-loop), which controls addition, replication, transcription and translation of mtDNA [11]. Transcription of mtDNA is dependent on the association between DNA-directed polymerase RNA mitochondrial (POLRMT) and two initiation factors: mitochondrial transcription factor A (TFAM) and mitochondrial transcription factor B1 or B2 (TFB1M or TFB2M) [21]. The expression of the mitochondrial genome is initiated by the transcription of mtDNA from bidirectional heavy- and lightstrand promoters to produce polycistronic transcripts [22]. The role of TFAM is to recruit POLRMT to the promoter initiation site in order for TFB2M to melt the promoter [23]. For the elongation stage, POLMRT requires transcription elongation factor (TEFM), which promotes POLRMT to form longer transcripts [24]. MtDNA replication is accomplished
Fig. 1 The circular human mitochondrial genome. The letters represent the tRNA genes. ND: NADH dehydrogenase; COX: Cytochrome C Oxidase; ATP6/8: ATP synthase genes 6 and 8

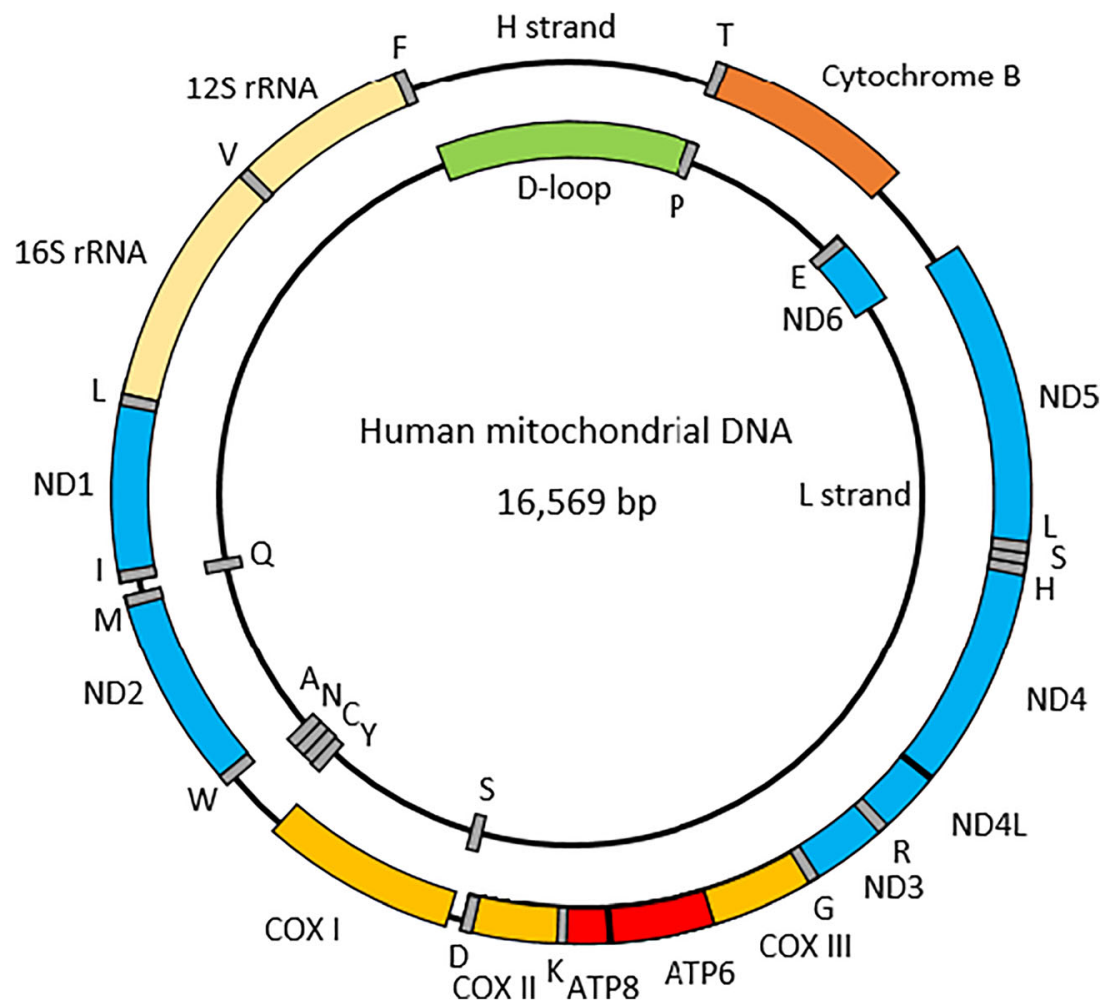


Table 1. The number of nuclear and mitochondrial genes for each respiratory complex

\begin{tabular}{llll}
\hline Complex & Genes nuclear DNA & Genes mitochondrial DNA & Total genes \\
\hline Complex I [14] (Blue) & 38 & 7 & 45 \\
Complex II [15] & 4 & 0 & 4 \\
Complex III [16] & 10 & 1 & 11 \\
(Orange) & 10 & 3 & 13 \\
Complex IV [17] & 14 & 2 & 16 \\
(Yellow) & \multicolumn{2}{l}{} \\
Complex V [18] (Red) & 14 &
\end{tabular}

The first column refers to the colour of the genes in Fig. 1 by various nuclear-encoded proteins. One of the proteins responsible is DNA polymerase $\gamma(\mathrm{POL} \gamma)$. POL $\gamma$ is a heterotrimer with two subunits POL $\gamma \mathrm{A}$, which proofreads newly synthesised DNA, and POL $\gamma \mathrm{B}$, which enhances interactions with the DNA template. Mutations in POL $\gamma$ A lead to the accumulation of genetic alterations in mtDNA [25].

\section{Genetics}

Within a eukaryotic cell, multiple mitochondria exist, that each contains 1 to $15 \mathrm{mtDNA}$ molecules. Mutations that affect all mtDNA copies are termed homoplasmic; mutated and wild-type DNA are also able to coexist in the same cell and are thus referred to as heteroplasmic. In contrast to nuclear DNA, the replication of mtDNA is not linked to the cell cycle, which allows some templates to replicate more than once during each cycle and others not at all [26]. In order for the mitochondria to become dysfunctional, a minimum amount of the mutated mtDNA has to be present in the cell, which is also referred to as the threshold level. This level, however, can be different between tissues due to the divergent energy dependence [27]. The threshold level of mutation is important for the clinical manifestations of the disease.

Mitochondrial DNA is inherited exclusively from maternal egg cells, because the paternal mitochondria and their DNA are actively eliminated [28]. As a result, fathers with mtDNA mutations are at no risk of transmitting the defect to their offspring. In addition, a mutation can occur de novo [29]. The risk of disease in offspring is dependent on the type of mutation and heteroplasmy in the mother. In the case of a homoplasmic mutation, all the maternal offspring will inherit the affected mtDNA. The penetrance, however, can be variable between patients, because it is also dependent on interactions with nuclear DNA. This is consistent with the role of nuclear genetic modifiers. Environmental factors can also contribute to the manifestation of the phenotype. When the mother carries a heteroplasmic mutation, both the normal and mutant mtDNA are randomly distributed to the daughter cells. This can lead to different levels of mutated mtDNA between offspring, depending on the number of mutated copies in the respective oocyte. But, as the mutated copies are randomly distributed during cell division after fertilisation, it can also lead to divergent mutant load between the various tissues in the offspring. This distribution of mutant mitochondria, however, is subject to the "bottleneck effect": during germ cell development, there is a reduction in mtDNA molecules, so that only a small number are present in oocytes [30]. Depending on the number of mutant mtDNA that was randomly chosen for a given cell, different ratios of healthy and mutant mitochondria will be present in the various oocytes [31]. In addition, there may be focal destruction of mutant mtDNA by autophagy or elimination of cells with a high load of mutant with mitochondria because of their reduced fitness [32]. These factors may explain why mitochondrial mutations do not affect all offspring, or even organs within the same individual, equally.

The mutation rate in the mitochondrial genome is 5 to 10 times greater than in the nuclear genome [33]. This can be attributed to the high amount of reactive oxygen species (ROS) in the mitochondria, that are produced during the ATP synthesis, which can damage mtDNA. Spontaneous mutations from ROS affect the mitochondrial genome more extensively than the nuclear genome. Reasons for this include the absence of protective histones in the mitochondria and the lack of efficient internal repair mechanisms for DNA in the mitochondrial genome compared to the nuclear genome. These mutations can lead to mitochondrial dysfunction, leading to a further increase in ROS production [34]. This progressive damage in the mitochondrial genome and the consequent decrease in mtDNA copy number is thought to contribute to ageing and has been associated with cardiovascular and chronic kidney disease [35]. Generally, the mutations in mtDNA are mostly located in the genes involved in maintenance, transcription, and translation of mtDNA such as transfer and ribosomal RNAs as opposed to in the genes encoding for the OXPHOS subunits [36]. Yet, regardless of the location of the mtDNA mutation, renal manifestations and especially proximal tubulopathy have been reported. 
Table 2. Overview of mitochondrial mutations reported in patients with proximal tubular dysfunction

\begin{tabular}{lll}
\hline Category & Mutation & Reference \\
\hline Isolated proximal tubulopathy & 2.8 kbp deletion & Szalbocs et al. [55] \\
KSS & 5 kbp deletion & Shoffner et al. [50] \\
KSS & 5.4 kbp deletion & Mori et al. [48] \\
KSS/PMPS & 7.4 kbp deletion & Lee et al. [54] \\
PMPS & 3.3 kbp deletion & Solano et al. [45] \\
PMPS & 4977 bp deletion & Niaudet et al. [51] \\
PMPS & 5.7 kbp deletion & Majander et al. [52] \\
CCO & 7.3 kbp deletion & Au et al. [53] \\
\hline
\end{tabular}

\section{Tubular defects}

\section{Proximal tubular dysfunction}

A generalised impairment of proximal tubule function is called renal Fanconi syndrome (RFS), and is characeterised by decreased reabsorption of various filtered solutes, such as electrolytes, sugars, amino acids and proteins [37]. Features typically associated with RFS include low molecular weight proteinuria, generalised aminoaciduria, hypophosphatemia (with or without bone disease), non-diabetic glycosuria, hypouricosuria and proximal renal tubular acidosis. If a renal biopsy is performed it will typically show dysmorphic mitochondria on electron microscopy [38]. However, the manifestation of RFS can differ between these patients, depending on the severity of the tubular dysfunction. Accordingly, the renal manifestations could be limited to a subset of the beforementioned abnormalities [37]. Besides mitochondrial mutations, this disorder can result from many other causes such as inherited metabolic disease or toxic agents.

\section{Mutations}

Renal manifestations without any extra-renal dysfunction may be the first clinical symptom of mitochondrial disorders, since proximal tubule cells are highly dependent on ATP provision [39]. However, ultimately, multiple organs may be affected with consequent neurological symptoms, myopathy, deafness or cardiac problems [40-43]. In fact, these other symptoms may predominate and kidney involvement is only recognised later: multiple cases have been reported of patients initially diagnosed with Pearson's marrow-pancreas syndrome (PMPS), defined by sideroblastic anaemia and pancreas dysfunction, who also developed RFS [44 46]. Similar reports exist for Kearns-Sayre (KSS) [47-50] and Leigh syndrome [40]. Several studies have found large mtDNA deletions in mitochondrial DNA to be the underlying cause, ranging from 2.7 to $7.4 \mathrm{kbp}$ deletions [48, 51-55]. Overall, these patients show phenotypic similarities to Pearson and Kearns-Sayre syndromes. Furthermore, RFS can be a symptom of cytochrome $\mathrm{C}$ oxidase (CCO) deficiency [41, 56]. After analysis of the respiratory chain complexes using muscle biopsies, complex III and IV were found to have a decreased activity $[39,42,43,48]$.

\section{Distal tubular dysfunction}

In addition to proximal tubulopathy, there have also been patients described suffering from specific electrolyte disturbances, most commonly hypomagnesemia and hypokalaemia. The key nephron segment for regulated magnesium reabsorption is the distal convoluted tubule (DCT) and its high-energy consumption makes it vulnerable to mitochondrial dysfunction [57]. Several cases have been described of patients suffering from electrolyte disturbances, consistent with DCT dysfunction. Again, many of these patients have multisystem disorders, such as Kearns-Sayre syndrome [58-60] or Leigh syndrome [61].
Table 3. Overview of mitochondrial mutations reported in patients with distal tubular dysfunction.

\begin{tabular}{lll}
\hline Category & Mutation & Reference \\
\hline Hypomagnesemia and hypokalaemia & T4291C & Wilson et al. [8] \\
Hypomagnesemia and hypokalaemia & $8.8 \mathrm{kbp}$ deletion & Goto et al. [49] \\
Hypoparathyroidism & $7813 \mathrm{bp}$ deletion & Wilichowski et al. [65] \\
& $8348 \mathrm{bp}$ deletion & \\
& $8587 \mathrm{bpdeletion}$ & \\
& $9485 \mathrm{bp}$ deletion & \\
Hypoparathyroidism & $6 \mathrm{kbp}$ deletion & Lee et al. [67] \\
Hypoparathyroidism & $6741 \mathrm{bp}$ deletion & Isotani et al. [68] \\
Hypoparathyroidism with hypomagnesemia and hypokalaemia & $8661 \mathrm{bpdeletion}$ & Emma et al. [70] \\
Tubulopathy with PMPS & $8034 \mathrm{bp}$ deletion & Van Ouweland et al. [71]
\end{tabular}


Table 4. Overview of mitochondrial mutations reported in patients with nephrotic syndrome

\begin{tabular}{lll}
\hline Category & Mutation & Reference \\
\hline FSGS & A3243G & Dinour et al. [73] \\
End stage renal disease (FSGS) & A3243G & Mima et al. [74] \\
FSGS & A4269G & Taniike et al. [76] \\
FSGS & G5538A & Lim et al. [77] \\
FSGS & A5728G & Meulemans et al. [79] \\
FSGS & A5843G & Scaglia et al. [78] \\
FSGS & 2905 bp deletion & Becher et al. [80] \\
\hline
\end{tabular}

\section{Mutations}

Numerous patients were found to have hypoparathyroidism leading to hypocalcaemia and hyperphosphatemia [58, 60, 62-68]. Magnesium is an important co-factor for the release of PTH hormone and thus, hypoparathyroidism is a common consequence of hypomagnesemia [69]. Magnesium levels were, however, not checked in every patient with hypoparathyroidism, but were significantly decreased in multiple cases [58, 61, 62, 66, 67]. Furthermore, most patients with hypomagnesemia also suffered from hypokalaemia [61, 62, 67]. Overall, these patients also suffered from sensorineural hearing deficits and myopathic symptoms. In a few cases, a clear deletion in mitochondrial DNA was found, ranging from 6 kbp to $8.8 \mathrm{kbp}$ (Table 3) [49, 65, 67, 70, 71].

A classical description of a mitochondrial cytopathy with DCT dysfunction was described in a large pedigree [8]. Symptoms included hypertension, hypercholesterolemia and hypomagnesemia with hypokalaemia and hypocalciuria, the electrolyte abnormalities being typical for DCT dysfunction. The symptoms segregated with a mtDNA mutation T4291C (Table 3) located 5' to the anticodon in the mitochondrial tRNA ${ }^{\text {Ile }}$ gene. Further symptoms included migraine headache, sensorineural hearing loss and hypertrophic cardiomyopathy, which are all phenotypes associated with mitochondrial dysfunction.

Table 5. Overview of mitochondrial mutations reported in patients with tubulointerstitial nephritis

\begin{tabular}{lll}
\hline Category & Mutation & Reference \\
\hline TIN & A547T & Connor et al. [85] \\
TIN & G586A & D'Aco et al. [83] \\
TIN & A608G & Tzen et al. [84] \\
TIN & T616C & Connor et al. [85] \\
TIN & A5656G & Zsurka et al. [86] \\
\hline
\end{tabular}

\section{Non-tubular manifestations}

\section{Nephrotic syndrome}

It is not only tubular function that is affected by mitochondrial cytopathies in the kidney. Podocytes also have mitochondria and are energy-dependent. Steroid-resistant NS is a common manifestation of mitochondrial dysfunction associated with coenzyme Q deficiency, which is important to recognise, as it is treatable by ubiquinone supplementation [72]. But nephrotic syndrome (NS) can also be seen with mtDNA mutations. Focal segmental glomerulosclerosis (FSGS) is a typical histological feature seen in degenerative glomerular disorders.

\section{Mutations}

The point mutation m.A3243G, affecting tRNA leucine, is known in patients suffering from myopathy, encephalopathy, lactic acidosis, and stroke-like episodes (MELAS). This mutation has also been described in patients with FSGS [73]. Interestingly, a patient suffering from MELAS with the A3234G mutation was found to have end-stage renal disease with glomerulosclerosis and interstitial fibrosis [74]. This mutation is of particular interest in adults with mtDNA-related disease, as it is the most commonly found mutation [75]. Patients typically present with diabetes and/or hearing loss and the spectrum of renal manifestation besides nephrotic syndrome can include also proximal and/or distal impairment [75]. Different point tRNA mutations can also result in FSGS [76-79]. Besides point mutations, a 2,905 bp deletion was found to result in FSGS, followed by necrotising nephritis with chronic interstitial nephritis [80].

\section{Tubulointerstitial nephritis}

Tubulointerstitial nephritis (TIN) is characterised by the infiltration of the kidney interstitium by inflammatory cells, which can ultimately cause reduced excretory renal function [81]. The phenotype is generally kidney failure and low molecular weight ('tubular') proteinuria, which are signs of proximal 
tubular dysfunction [82]. It is most often caused by drug reactions; however, it may also be caused by infections or systemic disease. Dysregulation of apoptosis has been proposed as a mechanism of pathogenesis of inflammatory processes in mitochondrial TIN. Interestingly, a mitochondrial mutation in the renal epithelial tissue may lead to inflammation while the liver, heart and brain remain unaffected.

\section{Mutations}

In patients with tubulointerstitial nephritis, multiple mutations in $\mathrm{tRNA}^{\text {Phe }}$ were identified [83-85]. Moreover, in a family diagnosed with severe progressive tubulointerstitial nephritis the mutation A5656G was detected [86].

\section{Genotype-phenotype}

When reviewing mutations in the three clinical categories, it becomes apparent that there is no obvious genotypephenotype correlation: large mitochondrial deletions can be associated with proximal and distal tubular dysfunction, as well as nephrotic syndrome. Similarly, the most common mitochondrial mutation, A3234G, has initially been associated primarily with FSGS, but a more comprehensive study of adults with mitochondrial disease showed manifestations also included hypophosphatemia, elevated urinary retinol-binding protein and hypomagnesemia, as well as no obvious renal involvement [75]. This variability was also reflected in the extra-renal manifestations, which ranged from maternally inherited diabetes and deafness to MELAS and myoclonic encephalopathy with ragged red fibres.

\section{Treatment}

Since there is not yet a cure for mitochondrial diseases, the current approach is to treat these patients with the aim to alleviate symptoms and slow progression of the disease. Typically, treatment consists of dietary supplements, predominantly antioxidants, such as vitamin C, E, and K (40-160 mg/ day), because they are thought to be effective against the damage caused by ROS generation [87]. These vitamins are electron acceptors, which allows them to bypass complex III deficiencies. However, there is no sufficient evidence for the actual benefit [88]. Riboflavin (50-400 mg/day), also known as vitamin $\mathrm{B}_{2}$, acts as a flavoprotein precursor in complexes I and II and is shown to be efficient in the C-1 and C-II deficiencies [89]. Folic acid also belongs to the $\mathrm{B}$ vitamins family and is involved in protein synthesis in mitochondria. Folate deficiency is common in patients with mitochondrial cytopathies and is often found in patients with Kearns-Sayre syndrome [90]. Furthermore, Coenzyme Q10 (CoQ10) (80-
$300 \mathrm{mg} /$ day) is most often prescribed for patients with complex III deficiencies, but also affects complexes I and II. It is important for the mitochondrial electron transport chain, because it can move electrons from complex I to II and transfer them to complex III [91]. Other treatments are $\alpha$-lipoic acid (suggested dosage 5-200 mg/day), which is an antioxidant that can decrease the ROS generated by OXPHOS, therefore decreasing oxidative stress in mitochondria [92], and LArginine (150-300 mg/kg/day), a nitric oxide precursor [93, 94]. While these treatments focus on improving the function of the mitochondria, organ-specific interventions, such as kidney transplantation, can also be used as treatment. Treating mitochondrial diseases, however, remains challenging, because the phenotype of the disease in each family is quite variable, and so are the responses to medications. Nuclear genetic modifiers could influence the response drastically.

Patients with mitochondrial disorders can receive genetic counselling to try to prevent disease transmission. However, due to the complexity of the inheritance of mtDNA this remains difficult. To avoid transmission, the most reliable method is to use a donor oocyte. The major limitation is the lack of a child who is biologically related to both parents. Another approach is pronuclear transfer. This technique involves the transfer of the pronuclei from one zygote to another, which results in a zygote containing nuclear DNA from the parents but mtDNA from a donor [95].

\section{Conclusion and future perspective}

In summary, the identification of the different mutations in mitochondrial DNA has enabled us to have a better understanding of the effect of mitochondrial dysfunction on target tissues, including the renal epithelium. A proximal tubulopathy is the most common tubular manifestation, but other patterns of electrolyte abnormalities have also been reported suggesting the involvement of other tubular segments, especially the DCT. Moreover, non-tubular defects due to mitochondrial mutations have been described. A better understanding of the precise disease mechanisms is needed to facilitate improved treatments.

Open Access This article is licensed under a Creative Commons Attribution 4.0 International License, which permits use, sharing, adaptation, distribution and reproduction in any medium or format, as long as you give appropriate credit to the original author(s) and the source, provide a link to the Creative Commons licence, and indicate if changes were made. The images or other third party material in this article are included in the article's Creative Commons licence, unless indicated otherwise in a credit line to the material. If material is not included in the article's Creative Commons licence and your intended use is not permitted by statutory regulation or exceeds the permitted use, you will need to obtain permission directly from the copyright holder. To view a copy of this licence, visit http://creativecommons.org/licenses/by/4.0/. 


\section{References}

1. Osellame LD, Blacker TS, Duchen MR (2012) Cellular and molecular mechanisms of mitochondrial function. Best Pract Res Clin Endocrinol Metab 26(6):711-723

2. Munnich A, Rustin P, Rötig A, Chretien D, Bonnefont J-P, Nuttin C, Cormier V, Vassault A, Parvy P, Bardet J, Charpentier C, Rabier D, Saudubray J-M (1992) Clinical aspects of mitochondrial disorders. J Inherit Metab Dis 15(4):448-455

3. Thorburn DR (2004) Mitochondrial disorders: prevalence, myths and advances. J Inherit Metab Dis 27(3):349-362

4. Bannwarth S, Procaccio V, Lebre AS, Jardel C, Chaussenot A, Hoarau C, Maoulida H, Charrier N, Gai X, Xie HM, Ferre M, Fragaki K, Hardy G, Mousson de Camaret B, Marlin S, Dhaenens CM, Slama A, Rocher C, Paul Bonnefont J, Rötig A, Aoutil N, Gilleron M, Desquiret-Dumas V, Reynier P, Ceresuela J, Jonard L, Devos A, Espil-Taris C, Martinez D, Gaignard P, Le Quan Sang K-H, Amati-Bonneau P, Falk MJ, Florentz C, Chabrol B, Durand-Zaleski I, Paquis-Flucklinger V (2013) Prevalence of rare mitochondrial DNA mutations in mitochondrial disorders. J Med Genet 50(10):704-714

5. Bhargava P, Schnellmann RG (2017) Mitochondrial energetics in the kidney. Nat Rev Nephrol 13(10):629-646

6. Kleta R, Bockenhauer D (2018) Salt-losing tubulopathies in children: what's new, what's controversial? J Am Soc Nephrol JASN 29(3):727-739

7. Chevalier RL (2016) The proximal tubule is the primary target of injury and progression of kidney disease: role of the glomerulotubular junction. Am J Physiol Ren Physiol 311(1): F145-F161

8. Wilson FH, Hariri A, Farhi A, Zhao H, Petersen KF, Toka HR, Nelson-Williams C, Raja KM, Kashgarian M, Shulman GI, Scheinman SJ, Lifton RP (2004) A Cluster of Metabolic Defects Caused by Mutation in a Mitochondrial tRNA. Science 306(5699): 1190-1194

9. El-Hattab AW, Craigen WJ, Scaglia F (2017) Mitochondrial DNA maintenance defects. Biochim Biophys Acta Mol basis Dis 1863(6):1539-1555

10. Anderson S, Bankier AT, Barrell BG, de Bruijn MHL, Coulson AR, Drouin J, Eperon IC, Nierlich DP, Roe BA, Sanger F, Schreier PH, Smith AJH, Staden R, Young IG (1981) Sequence and organization of the human mitochondrial genome. Nature 290(5806):457-465

11. Taanman J-W (1999) The mitochondrial genome: structure, transcription, translation and replication. Biochim Biophys Acta BBA Bioenerg 1410(2):103-123

12. Koopman WJH, Distelmaier F, Smeitink JA, Willems PH (2013) OXPHOS mutations and neurodegeneration. EMBO J 32(1):9-29

13. Calvo SE, Mootha VK (2010) The mitochondrial proteome and human disease. Annu Rev Genomics Hum Genet 11:25-44

14. Sharma LK, Lu J, Bai Y (2009) Mitochondrial respiratory complex I: structure, function and implication in human diseases. Curr Med Chem 16(10):1266-1277

15. Cecchini G (2003) Function and structure of complex II of the respiratory chain. Annu Rev Biochem 72(1):77-109

16. Bénit $P$, Lebon $S$, Rustin $P$ (2009) Respiratory-chain diseases related to complex III deficiency. Biochim Biophys Acta BBA - Mol Cell Res 1793(1):181-185

17. Saraste M (1983) How complex is a respiratory complex? Trends Biochem Sci 8(4):139-142

18. Jonckheere AI, Smeitink JAM, Rodenburg RJT (2012) Mitochondrial ATP synthase: architecture, function and pathology. $\mathrm{J}$ Inherit Metab Dis 35(2):211-225

19. Kim KM, Noh JH, Abdelmohsen K, Gorospe M (2017) Mitochondrial noncoding RNA transport. BMB Rep 50(4):164 174
20. Attardi G, Schatz G (1988) Biogenesis of mitochondria. Annu Rev Cell Biol 4:289-333

21. Falkenberg M, Gaspari M, Rantanen A, Trifunovic A, Larsson NG, Gustafsson CM (2002) Mitochondrial transcription factors B1 and B2 activate transcription of human mtDNA. Nat Genet 31(3): 289-294

22. Bonawitz ND, Clayton DA, Shadel GS (2006) Initiation and beyond: multiple functions of the human mitochondrial transcription machinery. Mol Cell 24(6):813-825

23. Ramachandran A, Basu U, Sultana S, Nandakumar D, Patel SS (2017) Human mitochondrial transcription factors TFAM and TFB2M work synergistically in promoter melting during transcription initiation. Nucleic Acids Res 45(2):861-874

24. Posse V, Shahzad S, Falkenberg M, Hällberg BM, Gustafsson CM (2015) TEFM is a potent stimulator of mitochondrial transcription elongation in vitro. Nucleic Acids Res 43(5):2615-2624

25. Carrodeguas JA, Theis K, Bogenhagen DF, Kisker C (2001) Crystal structure and deletion analysis show that the accessory subunit of mammalian DNA polymerase gamma, Pol gamma $\mathrm{B}$, functions as a homodimer. Mol Cell 7(1):43-54

26. Clayton DA (1982) Replication of animal mitochondrial DNA. Cell. 28(4):693-705

27. Rossignol R, Faustin B, Rocher C, Malgat M, Mazat J-P, Letellier T (2003) Mitochondrial threshold effects. Biochem J 370(Pt 3):751762

28. Sato M, Sato K (2012) Maternal inheritance of mitochondrial DNA: degradation of paternal mitochondria by allogeneic organelle autophagy, allophagy. Autophagy. 8(3):424-425

29. Sallevelt SCEH, de Die-Smulders CEM, Hendrickx ATM, Hellebrekers DMEI, de Coo IFM, Alston CL, Knowles C, Taylor RW, McFarland R, Smeets HJM (2017) De novo mtDNA point mutations are common and have a low recurrence risk. J Med Genet 54(2):73-83

30. Marlow FL (2017) Mitochondrial matters: mitochondrial bottlenecks, self-assembling structures, and entrapment in the female germline. Stem Cell Res 21:178-186

31. Khrapko K (2008) Two ways to make a mtDNA bottleneck. Nat Genet 40(2):134-135

32. Zhang H, Burr SP, Chinnery PF (2018) The mitochondrial DNA genetic bottleneck: inheritance and beyond. Essays Biochem 62(3): 225-234

33. Brown WM, George M, Wilson AC (1979) Rapid evolution of animal mitochondrial DNA. Proc Natl Acad Sci U S A 76(4): 1967-1971

34. Wei YH (1998) Oxidative stress and mitochondrial DNA mutations in human aging. Proc Soc Exp Biol Med Soc Exp Biol Med N Y N 217(1):53-63

35. Fazzini F, Lamina C, Fendt L, Schultheiss UT, Kotsis F, Hicks AA, Meiselbach H, Weissensteiner H, Forer L, Krane V, Eckardt K-U, Köttgen A, Kronenberg F, Eckardt K-U, Meiselbach H, Schneider M, Dienemann T, Prokosch H-U, Bärthlein B, Beck A, Ganslandt T, Reis A, Ekici AB, Avendaño S, Becker-Grosspitsch D, AlberthSchmidt U, Hausknecht B, Zitzmann R, Weigel A, Walz G, Köttgen A, Schultheiß U, Kotsis F, Meder S, Mitsch E, Reinhard U, Floege J, Schlieper G, Saritas T, Ernst S, Beaujean N, Schaeffner E, BaidAgrawal S, Theisen K, Haller H, Menne J, Zeier M, Sommerer C, Woitke R, Wolf G, Busch M, Fuß R, Sitter T, Blank C, Wanner C, Krane V, Börner-Klein A, Bauer B, Kronenberg F, Raschenberger J, Kollerits B, Forer L, Schönherr S, Weissensteiner H, Oefner P, Gronwald W, Zacharias H, Schmid M, Nadal J (2019) Mitochondrial DNA copy number is associated with mortality and infections in a large cohort of patients with chronic kidney disease. Kidney Int 96(2):480-488

36. Smits P, Smeitink J, van den Heuvel L (2010) Mitochondrial Translation and Beyond: Processes Implicated in Combined 
Oxidative Phosphorylation Deficiencies. J Biomed Biotechnol 2010:737385

37. Klootwijk ED, Reichold M, Unwin RJ, Kleta R, Warth R, Bockenhauer D (2015) Renal Fanconi syndrome: taking a proximal look at the nephron. Nephrol Dial Transplant 30(9):1456-1460

38. Thorner PS, Balfe JW, Becker LE, Baumal R (1985) Abnormal Mitochondria on a renal biopsy from a case of mitochondrial myopathy. Pediatr Pathol 4(1-2):25-35

39. Kuwertz-Bröking E, Koch HG, Marquardt T, Rossi R, Helmchen U, Müller-Höcker J, Harms E, Bulla M (2000) Renal Fanconi syndrome: first sign of partial respiratory chain complex IV deficiency. Pediatr Nephrol 14(6):495-49

40. Ogier H, Lombes A, Scholte HR, Poll-The BT, Fardeau M, Alcardi J, Vignes B, Niaudet P, Saudubray JM (1988) de Toni-FanconiDebré syndrome with leigh syndrome revealing severe muscle cytochrome c oxidase deficiency. J Pediatr 112(5):734-739

41. Van Biervliet JPGM, Bruinvis L, Ketting D, De Bree PK, Der Heiden CV, Wadman SK, Willems JL, Bookelman H, Haelst UV, Monnens LAH (1977) Hereditary mitochondrial myopathy with lactic acidemia, a De Toni-Fanconi-Debré syndrome, and a defective respiratory chain in voluntary striated muscles. Pediatr Res 11(10): 1088

42. Sperl W, Ruitenbeek W, Trijbels JMF, Sengers RCA, Stadhouders AM, Guggenbichler JP (1988) Mitochondrial myopathy with lactic acidaemia, Fanconi-De Toni-Debre syndrome and a disturbed succinate: cytochrome c oxidoreductase activity. Eur J Pediatr 147(4): 418-421

43. Morris AAM, Taylor RW, Birch-Machin MA, Jackson MJ, Coulthard MG, Bindoff LA, Welch RJ, Howell N, Turnbull DM (1995) Neonatal Fanconi syndrome due to deficiency of complex III of the respiratory chain. Pediatr Nephrol 9(4):407-411

44. Atale A, Bonneau-Amati P, Rötig A, Fischer A, Perez-Martin S, de Lonlay P, Niaudet P, De Parscau L, Mousson C, Thauvin-Robinet C, Munnich A, Huet F, Faivre L (2009) Tubulopathy and pancytopaenia with normal pancreatic function: A variant of Pearson syndrome. Eur J Med Genet 52(1):23-26

45. Solano A, Russo G, Playan A, Parisi M, Palumbo M, Renis M, López-Pérez MJ, Andreu AL, Montoya J, DiPietro M, Scuderi A (2004) De Toni-Debre-Fanconi syndrome due to a palindromeflanked deletion in mitochondrial DNA. Pediatr Nephrol 19(7): 790-793

46. Gilbert RD, Paed FC, Emms M, Tech DM (1996) Pearson's Syndrome Presenting with Fanconi Syndrome. Ultrastruct Pathol 20(5):473-475

47. Mihai CM, Catrinoiu D, Toringhibel M, Stoicescu RM, Hancu A (2009) De Toni-Debré-Fanconi syndrome in a patient with KearnsSayre syndrome: a case report. J Med Case Reports 3(1):101

48. Mori K, Narahara K, Ninomiya S, Goto Y, Nonaka I (1991) Renal and skin involvement in a patient with complete Kearns-Sayre syndrome. Am J Med Genet 38(4):583-587

49. Goto Y, Itami N, Kajii N, Tochimaru H, Endo M, Horai S (1990) Renal tubular involvement mimicking Bartter syndrome in a patient with Kearns-Sayre syndrome. J Pediatr 116(6):904-910

50. Shoffner JM, Voljavec AS, Dixon J, Kaufman A, Wallace DC, Mitch WE (1995) Renal amino acid transport in adults with oxidative phosphorylation diseases. Kidney Int 47(4):1101-1107

51. Niaudet P, Heidet L, Munnich A, Schmitz J, Bouissou F, Gubler MC, Rötig A (1994) Deletion of the mitochondrial DNA in a case of de Toni-Debre-Fanconi syndrome and Pearson syndrome. Pediatr Nephrol 8(2):164-168

52. Majander A, Suomalainen A, Vettenranta K, Sariola H, Perkio M, Holmberg C, Pihko H (1991) Congenital Hypoplastic Anemia, Diabetes, and Severe Renal Tubular Dysfunction Associated with a Mitochondrial DNA Deletion. Pediatr Res 30(4):327-330
53. Au KM, Lau SC, Mak YF, Lai WM, Chow TC, Chen ML, Chiu MC, Chan AYW (2007) Mitochondrial DNA deletion in a girl with Fanconi's syndrome. Pediatr Nephrol 22(1):136-140

54. Lee JJ, Tripi LM, Erbe RW, Garimella-Krovi S, Springate JE (2012) A mitochondrial DNA deletion presenting with corneal clouding and severe Fanconi syndrome. Pediatr Nephrol 27(5):869-872

55. Szabolcs MJ, Seigle R, Shanske S, Bonilla E, DiMauro S, D’Agati V (1994) Mitochondrial DNA deletion: a cause of chronic tubulointerstitial nephropathy. Kidney Int 45(5):1388-1396

56. Das AM, Schweitzer-Krantz S, Byrd DJ, Brodehl J (1994) Absence of cytochrome $\mathrm{c}$ oxidase activity in a boy with dysfunction of renal tubules, brain and muscle. Eur J Pediatr 153(4):267-270

57. Reilly RF, Ellison DH (2000) Mammalian distal tubule: physiology, pathophysiology, and molecular anatomy. Physiol Rev 80(1):277313

58. Toppet M (1977) Oculocraniosomatic Neuromuscular Disease With Hypoparathyroidism. Arch Pediatr Adolesc Med 131(4):437

59. Rheuban KS, Ayres NA, Duncan Sellers T, DiMarco JP (1983) Near-fatal Kearns-Sayre Syndrome: A Case Report and Review of Clinical Manifestations. Clin Pediatr (Phila) 22(12):822-825

60. Dewhurst AG, Hall D, Schwartz MS, McKeran RO (1986) KearnsSayre syndrome, hypoparathyroidism, and basal ganglia calcification. J Neurol Neurosurg Psychiatry 49(11):1323-1324

61. Simopoulos AP, Delea CS, Bartter FC (1971) Neurodegenerative disorders and hyperaldosteronism. J Pediatr 79(4):633-641

62. Harvey JN, Barnett D (1992) Endocrine dysfunction in KearnsSayre syndrome. Clin Endocrinol 37(1):97-104

63. Pellock JM, Behrens M, Lewis L, Holub D, Cartter S, Rowland LP (1978) Kearns-Sayre syndrome and hypoparathyroidism. Ann Neurol 3(5):455-458

64. Allen RJ, DiMauro S, Coulter DL, Papadimitriou A, Rothenberg SP (1983) Kearns-sayre syndrome with reduced plasma and cerebrospinal fluid folate. Ann Neurol 13(6):679-682

65. Wilichowski E, Grüters A, Kruse K, Rating D, Beetz R, Korenke GC, Ernst BP, Christen H-J, Hanefeld F (1997) Hypoparathyroidism and Deafness Associated with Pleioplasmic Large Scale Rearrangements of the Mitochondrial DNA: A Clinical and Molecular Genetic Study of Four Children with Kearns-Sayre Syndrome. Pediatr Res 41(2):193-200

66. Katsanos KH, Elisaf M, Bairaktari E, Tsianos EV (2001) Severe hypomagnesemia and hypoparathyroidism in Kearns-Sayre syndrome. Am J Nephrol 21(2):150-153

67. Lee YS, Yap HK, Barshop BA, Lee YS, Rajalingam S, Loke KY (2001) Mitochondrial tubulopathy: the many faces of mitochondrial disorders. Pediatr Nephrol 16(9):710-712

68. Isotani H, Fukumoto Y, Kawamura H, Furukawa K, Ohsawa N, Goto Y, Nishino I, Nonaka I (1996) Hypoparathyroidism and insulin-dependent diabetes mellitus in a patient with Kearns-Sayre syndrome harbouring a mitochondrial DNA deletion. Clin Endocrinol (Oxf) 45(5):637-641

69. Astor MC, Løvås K, Wolff ASB, Nedrebø B, Bratland E, SteenJohnsen J, Husebye ES (2015) Hypomagnesemia and functional hypoparathyroidism due to novel mutations in the $\mathrm{Mg}$-channel TRPM6. Endocr Connect 4(4):215-222

70. Emma F, Pizzini C, Tessa A, Di Giandomenico S, Onetti-Muda A, Santorelli FM, Bertini E, Rizzoni G (2006) "Bartter-like" phenotype in Kearns-Sayre syndrome. Pediatr Nephrol 21(3):355-360

71. Ouweland J van den, Klerk J de, Corput M van de, Dirks RW, Raap AK, Scholte HR, Huijmans JGM, Hart L 't, Bruining GJ, Maassen JA (2000) Characterization of a novel mitochondrial DNA deletion in a patient with a variant of the Pearson marrow-pancreas syndrome. Eur J Hum Genet 8(3):195

72. Starr MC, Chang IJ, Finn LS, Sun A, Larson AA, Goebel J, Hanevold C, Thies J, Van Hove JLK, Hingorani SR, Lam C (2018) COQ2 nephropathy: a treatable cause of nephrotic syndrome in children. Pediatr Nephrol Berl Ger 33(7):1257-1261 
73. Dinour D, Mini S, Polak-Charcon S, Lotan D, Holtzman EJ (2004) Progressive nephropathy associated with mitochondrial tRNA gene mutation. Clin Nephrol 62(2):149-154

74. Mima A, Shiota F, Matsubara T, Iehara N, Akagi T, Abe H, Nagai K, Matsuura M, Murakami T, Kishi S, Araoka T, Kishi F, Kondo N, Shigeta R, Yoshikawa K, Kita T, Doi T, Fukatsu A (2011) An autopsy case of mitochondrial myopathy, encephalopathy, lactic acidosis, and stroke-like episodes (MELAS) with intestinal bleeding in chronic renal failure. Ren Fail 33(6):622-625

75. Hall AM, Vilasi A, Garcia-Perez I, Lapsley M, Alston CL, Pitceathly RDS, McFarland R, Schaefer AM, Turnbull DM, Beaumont NJ, Hsuan JJ, Cutillas PR, Lindon JC, Holmes E, Unwin RJ, Taylor RW, Gorman GS, Rahman S, Hanna MG (2015) The urinary proteome and metabonome differ from normal in adults with mitochondrial disease. Kidney Int 87(3):610-622

76. Taniike M, Fukushima H, Yanagihara I, Tsukamoto H, Tanaka J, Fujimura H, Nagai T, Sano T, Yamaoka K, Inui K (1992) Mitochondrial tRNA(Ile) mutation in fatal cardiomyopathy. Biochem Biophys Res Commun 186(1):47-53

77. Lim K, Steele D, Fenves A, Thadhani R, Heher E, Karaa A (2017) Focal segmental glomerulosclerosis associated with mitochondrial disease. Clin Nephrol Case Stud 5:20-25

78. Scaglia F, Vogel H, Hawkins EP, Vladutiu GD, Liu L-L, Wong LJC (2003) Novel homoplasmic mutation in the mitochondrial tRNATyr gene associated with atypical mitochondrial cytopathy presenting with focal segmental glomerulosclerosis. Am J Med Genet A 123A(2):172-178

79. Meulemans A, Seneca S, Lagae L, Lissens W, De Paepe B, Smet J, Van Coster R, De Meirleir L (2006) A novel mitochondrial transfer RNA(Asn) mutation causing multiorgan failure. Arch Neurol 63(8):1194-1198

80. Becher MW, Wills ML, Noll WW, Hurko O, Price DL (1999) Kearns-Sayre syndrome with features of Pearson's marrowpancreas syndrome and a novel 2905-base pair mitochondrial DNA deletion. Hum Pathol 30(5):577-581

81. Joyce E, Glasner P, Ranganathan S, Swiatecka-Urban A (2017) Tubulointerstitial nephritis: diagnosis, treatment, and monitoring. Pediatr Nephrol Berl Ger 32(4):577-587

82. Kodner CM, Kudrimoti A (2003) Diagnosis and management of acute interstitial nephritis. Am Fam Physician 67(12):2527-2534

83. D'Aco KE, Manno M, Clarke C, Ganesh J, Meyers KEC, Sondheimer N (2013) Mitochondrial tRNA(Phe) mutation as a cause of end-stage renal disease in childhood. Pediatr Nephrol Berl Ger 28(3):515-519

84. Tzen CY, Tsai JD, Wu TY, Chen BF, Chen ML, Lin SP, Chen SC (2001) Tubulointerstitial nephritis associated with a novel mitochondrial point mutation. Kidney Int 59(3):846-854
85. Connor TM, Hoer S, Mallett A, Gale DP, Gomez-Duran A, Posse V, Antrobus R, Moreno P, Sciacovelli M, Frezza C, Duff J, Sheerin NS, Sayer JA, Ashcroft M, Wiesener MS, Hudson G, Gustafsson CM, Chinnery PF, Maxwell PH (2017) Mutations in mitochondrial DNA causing tubulointerstitial kidney disease. PLOS Genet 13(3): e1006620

86. Zsurka G, Ormos J, Iványi B, Túri S, Endreffy E, Magyari M, Sonkodi S, Venetianer P (1997) Mitochondrial mutation as a probable causative factor in familial progressive tubulointerstitial nephritis. Hum Genet 99(4):484-487

87. Argov Z, Bank WJ, Maris J, Eleff S, Kennaway NG, Olson RE, Chance B (1986) Treatment of mitochondrial myopathy due to complex III deficiency with vitamins K3 and C: A 31P-NMR follow-up study. Ann Neurol 19(6):598-602

88. Parikh S, Saneto R, Falk MJ, Anselm I, Cohen BH, Haas R (2009) A Modern Approach to the Treatment of Mitochondrial Disease. Curr Treat Options Neurol 11(6):414-430

89. Bernsen PLJA, Gabreëls FJM, Ruitenbeek W, Hamburger HL (1993) Treatment of complex I deficiency with riboflavin. J Neurol Sci 118(2):181-187

90. Ormazabal A, Casado M, Molero-Luis M, Montoya J, Rahman S, Aylett S-B, Hargreaves I, Heales S, Artuch R (2015) Can folic acid have a role in mitochondrial disorders? Drug Discov Today 20(11): 1349-1354

91. Yubero D, Montero R, Armstrong J, Espinós C, Palau F, SantosOcaña C, Salviati L, Navas P, Artuch R (2015) Molecular diagnosis of coenzyme Q10 deficiency. Expert Rev Mol Diagn 15(8):10491059

92. Burke DG, Chilibeck PD, Parise G, Tarnopolsky MA, Candow DG (2003) Effect of alpha-lipoic acid combined with creatine monohydrate on human skeletal muscle creatine and phosphagen concentration. Int J Sport Nutr Exerc Metab 13(3):294-302

93. Ganetzky RD, Falk MJ (2018) 8-year retrospective analysis of intravenous arginine therapy for acute metabolic strokes in pediatric mitochondrial disease. Mol Genet Metab 123(3):301-308

94. Khan NA, Auranen M, Paetau I, Pirinen E, Euro L, Forsström S, Pasila L, Velagapudi V, Carroll CJ, Auwerx J, Suomalainen A (2014) Effective treatment of mitochondrial myopathy by nicotinamide riboside, a vitamin B3. EMBO Mol Med 6(6):721-731

95. Craven L, Tuppen HA, Greggains GD, Harbottle SJ, Murphy JL, Cree LM, Murdoch AP, Chinnery PF, Taylor RW, Lightowlers RN, Herbert M, Turnbull DM (2010) Pronuclear transfer in human embryos to prevent transmission of mitochondrial DNA disease. Nature 465(7294):82-85

Publisher's note Springer Nature remains neutral with regard to jurisdictional claims in published maps and institutional affiliations. 